\title{
EFEKTIFITAS PAPARAN ULTRA VIOLET SINAR MATAHARI TERHADAP KEPADATAN MASSA TULANG DAN KADAR KOLESTEROL PADA LANSIA
}

\section{THE EFFECTIVENESS AT ULTRAVIOLET SUN BONE EXPOSURE TO MASS DENSITY AND CHOLESTEROL LEVELS IN THE ELDERLY}

\author{
Cemy Nur Fitria ${ }^{1),}$ Anis Prabowo ${ }^{2)}$ \\ Prodi DIII Keperawatan STIKES PKU Muhammadiyah Surakarta \\ cemynurfitria@gmail.com dan anisprabo@gmail.com
}

\begin{abstract}
Abstrak
Sinar matahari merangsang tubuh memproduksi vitamin D. Paparan sinar matahari pada wajah, leher, lengan, dan kaki selama 10-15 menit dapat menghasilkan 1.000 unit internasional (IU) sampai $3.000 \mathrm{IU}$. Vitamin D juga dapat memberikan perlindungan osteoporosis dan rakhitis. Kejadian kolesterol yang tinggi pada lansia di wilayah kecamatan Banjarsari Surakarta 50 persen dari lansia yang ada. Ultraviolet B dari sinar matahari 30 menit tiga kali seminggu selama 12 minggu dapat memperbaiki status vitamin D. untuk Tujuan penelitian ini adalah untuk mengetahui efektifitas paparan sinar ultraviolet terhadap kadar kolesterol darah lansia. Metode penelitian eksperimen dengan pre test and post test with control group, sampel diambil secara total sampling. Uji yang digunakan untuk mengetahui keefektifan paparan sinar matahari dengan uji dependent $t$ test dan independent t-test. Hasil penelitian 15 responden kelompok intervensi terhadap kepadatan massa tulang $p$ value 0.007 dan kelompok kontrol p value 0,002 sehingga uji significancy bermakna Hasil penelitian 15 responden kelompok intervensi terhadap kadar kolesterol $p$ value 0.008 dibandingkan dengan kelompok kontrol terhadap kadar kolestrol mempunyai p value 0.001.

Kesimpulannya adalah paparan sinar matahari efektif meningkatkan kepadatan massa tulang dan menurunkan kadar kolesterol lansia. Sehingga lansia sangat bermanfaat melakukan paparan sinar matahari.
\end{abstract}

Kata Kunci: Sinar ultra violet sinar matahari, kepadatan massa tulang, kadar kolesterol, Lansia

\begin{abstract}
Sunlight stimulates the body to produce vitamin D. Exposure to sunlight on the face, neck, arms, and legs for 10-15 minutes can generate 1,000 international units (IU) to 3,000 IU. Vitamin D may also provide protection osteoporosis and rickets. The incidence of high cholesterol in the elderly in the districts of Banjarsari Surakarta was 50 percent of elderly people there. Ultraviolet B of sunshine 30 minutes three times a week for 12 weeks can improve the status of vitamin D. The objective at the research is to determine the effectiveness of ultraviolet light exposure on elderly blood cholesterol levels. The methods of experimental research with pre-test and post-test with control group. The samples were taken in total sampling. Test used to determine the effectiveness of sun exposure with dependent t-test and independent $t$-test. The results of 15 respondents at the intervention group, bone density $p$ value 0.007 and $p$ value 0,002 at control group so that the test significancy meaningful research results of 15 respondents to the intervention group $p$ value 0.008 cholesterol levels compared with the control group on cholesterol levels had p value 0.001. The conclusion is sun exposure increases bone density effectively and decrease cholesterol levels on elderly. So that the elderly are particularly helpful do sun exposure.
\end{abstract}

Key word: ultra violet sun rays, bone density, cholesterol levels, Elderly 


\section{PENDAHULUAN}

Pembentukan vitamin D pada tulang Terik sinar matahari tidak selalu berdampak negatif. Paparannya di pagi hari memiliki manfaat bagi kesehatan tulang karena menjadi sumber vitamin D. Paparan sinar matahari yang baik adalah sinar matahari pagi hari, sebelum pukul 09.00. Pada jam tersebut, matahari akan memberikan sinar yang bermanfaat bagi tubuh. Pada waktu berkas sinar ultraviolet menganai kulit maka sinar ini akan disaring di kulit, di bawah kulit terdapat sejumlah besar simpanan kolesterol. Sinar ultraviolet mengubah simpanan kolesterol ini menjadi vitamin D. Berdasarkan data USA Bureau of the Census, populasi lanjut usia Indonesia akan meningkat sebesar $414 \%$ dalam kurun waktu tahun 1990-2025. Peningkatan ini merupakan tertinggi di dunia (Darmojo dan Martono, 2006). Saat ini yaitu tahun 2010 mengalami peningkatan jumlah lanjut usia mencapai 9,58\% dan pada tahun 2020 diprediksi mengalami peningkatan sebesar $11,20 \%$. Usia harapan hidup penduduk Indonesia juga akan meningkat dari 65 tahun menjadi 73 tahun pada tahun 2025. Peningkatan usia harapan hidup menyebabkan pola distribusi penyakit bergeser dari penyakit infeksi beralih pada penyakit degeneratif. Salah satu penyakit degeneratif yang semakin tinggi angka prevalensinya dan perlu diwaspadai adalah osteoporosis (Suheimi, 2008)

Penelitian terbaru Yayasan Osteoporosis Internasional (IOF) mengungkapkan satu dari empat perempuan Indonesia usia 50-80 berisiko terkena osteoporosis. Risiko pada perempuan empat kali lebih tinggi dibandingkan laki-laki. Temuan lainnya, selama 30 tahun terakhir, insiden patah tulang pinggul meningkat dua hingga tiga kali lipat di sebagian besar negaranegara Asia. Kami memperkirakan di tahun 2050, akan ada lebih dari 50 persen insiden patah tulang pinggul di Asia yang terjadi karena osteoporosis," terang CEO IOF, Judy Stenmark melalui siaran pers yang diterima Kompas Health, Jumat (13/12/2013).

Penelitian dengan dukungan Fonterra (2013), ini bertujuan menghasilkan pemahaman lebih baik tentang kesehatan tulang di Asia Pasifik. Stenmark mengatakan meskipun prevalensi osteoporosis tinggi, gangguan ini masih kurang terdiagnosa, kurang terawat, dan kurang sumber daya dalam penanganannya. Pemahaman untuk mengurangi risiko osteoporosis juga masih rendah. Risiko bisa berkurang dengan langkah sederhana seperti diet kaya kalsium dan protein, kadar Vitamin D yang cukup, dan skema latihan teratur. Puncak kepadatan tulang kita berusia sekitar 30 tahun. Ketika kita mencapai usia ini tanpa gizi yang cukup dan olahraga teratur, tulang dapat menjadi kehilangan kepadatan atau melemah yang dapat menyebabkan osteoporosis," paparnya.

\section{METODE PENELITIAN}

Jenis penelitian yang digunakan dalam penelitian ini adalah eksperiment dengan rangcangan pretest - posttest design. Populasinya adalah lansia di posyandu Aisyiyah Sumber kecamatan Banjarsari Surakarta. Teknik pengambilan sampelnya menggunakan total sampling dengan 30 responden. Analisa data yang digunakan untuk menguji hipotetis yaitu menggunakan Statistik menggunakan uji beda tidak perpasangan yaitu Independen t-tes.

\section{HASIL DAN PEMBAHASAN \\ Hasil penelitian}

Karakteristik Responden.

Tabel 1. Distribusi Frekuensi Responden Berdasarkan Umur, Jenis Kelamin pada Kelompok Intervensi dan Kontrol

\begin{tabular}{lcc}
\hline $\begin{array}{c}\text { Karakteristik } \\
\text { responden }\end{array}$ & $\begin{array}{c}\text { Frekuensi } \\
\text { Kelompok }\end{array}$ & Persentase \\
\hline Umur & & \\
60-70 tahun & 12 & 42 \\
50-59 tahun & 10 & 33 \\
45-49 tahun & 8 & 25 \\
Jenis Kelamin & & \\
Laki-Laki & 6 & 20 \\
Perempuan & 24 & 80 \\
\hline \multicolumn{1}{c}{ Jumlah } & 20 & 100 \\
\hline
\end{tabular}

Berdasarkan tabel 1 menunjukkan bahwa responden kelompok intervensi dan kelompok kontrol mempunyai golongan umur responden terbanyak antara 60-70 tahun, frekuensi 12 dengan prosentase $42 \%$. Jenis kelamin responden yang paling banyak perempuan dengan frekuensi 24 dan prosenstase $80 \%$, sedangkan laki laki $20 \%$. 
Tabel 2 Distribusi Frekuensi Responden Berdasarkan Kepadatan Massa Tulang dan

Kadar Kolesterol pada Kelompok Intervensi dan Kontrol

\begin{tabular}{ccc}
\hline $\begin{array}{c}\text { Karakteristik } \\
\text { responden }\end{array}$ & $\begin{array}{c}\text { Frekuensi } \\
\text { Kelompok } \\
\text { Intervensi } \\
\text { pre test }\end{array}$ & $\begin{array}{c}\text { Frekuensi } \\
\text { Kelompok } \\
\text { Intervensi } \\
\text { post test }\end{array}$ \\
\hline $\begin{array}{c}\text { Kepadatan massa } \\
\text { tulang }\end{array}$ & & \\
$-4,5-(-4,0)$ & 7 & 2 \\
$-3,9-(-3,4)$ & 3 & 2 \\
$-3,3-(-3,0)$ & 2 & 2 \\
$-2,9-(-2,5)$ & 1 & 4 \\
$-2,4-(-2,0)$ & 3 & 3 \\
$<-2,0$ & 0 & 2 \\
Jumlah & 15 & 15 \\
Kadar kolesterol & & 5 \\
$<200$ & 0 & 5 \\
$200-220$ & 4 & 3 \\
$221-240$ & 4 & 0 \\
$241-250$ & 2 & 1 \\
$251-270$ & 1 & 1 \\
$271-290$ & 1 & 0 \\
$291-310$ & 1 & 0 \\
$311-330$ & 2 & \\
\hline Jumlah & 15 & \\
\hline
\end{tabular}

Berdasarkan tabel 2 menunjukkan bahwa responden kelompok intervensi pre test yang mempunyai kepadatan massa tulang dengan resiko tinggi $\mathrm{T}$-score $-4,5$ sampai $-4,0$ terbanyak dengan jumlah 7 responden setelah post test antara mempunyai kepadatan massa tulang responden terbanyak dengan $\mathrm{T}$ score -2,9 sampai 2,5 sebanyak 3 responden. Kadar kolesterol responden kelompok intervensi pre test dengan score 200-250 sebanyak 10 responden sedangkan 251-330 sebanyak 5 responden. Kadar kolesterol 200-250 sebanyak 8 responden sedangkan 251330 sebanyak 2 responden sedangkan score $<200$ sebanyak 5 responden.

Data kelompok kontrol kepadatan massa tulang dan kolesterol jumlah responden relatif stabil dengan rentang score sama.

\section{Analisis Kuantitatif}

Nilai rerata dari hasil penelitian ini adalah Kepadatan massa tulang lansia ada perubahan penurunan yang bermakna dengan hasil uji $t$ berpasangan dengan nilai $0,008 \quad(\mathrm{p}<0,05)$, sedangkat uji $\mathrm{T}$ tidak berpasangan nilai 0,001 . Rerata hasil penelitian terhadap kadar kolesterol dengan uji $\mathrm{T}$ bepasangan nilai 0,007 ( $\mathrm{p}>0,05)$, sedangkan uji $\mathrm{T}$ tidak berpasangan nilai 0,002 . Ada perubahan bermakna paparan ultraviolet sinar matahari terhadap kedua kadar kolesterol dan kepadatan massa tulang pada lansia.

\section{PEMBAHASAN}

Jenis kelamin wanita banyak yang mengalami osteoporosis, kehilangan massa tulang paling cepat terjadi setelah menoupause dan hal itu berlanjut terus. Osteoporosis yang sebagian besar mempengaruhi wanita juga mempengaruhi laki-laki yang akan berkembang ketika resorpsi tulang terjadi terlalu cepat atau ketika formasi terjadi terlalu lambat. Osteoporosis kemungkinan akan terjadi jika anda tidak mencapai massa tulang puncak selama waktu pembentukan tulang. Selama hidup, tulang yang tua disingkirkan (resorpsi) dan tulang yang baru dibentuk pada rangka (formasi).

Lansia yang melakukan paparan sinar ultraviolet jam 9 pagi selama 15 menit dengan frekuensi 3 kali secara langsung terhadap sinar matahari merangsang tubuh memproduksi vitamin D. Paparan sinar matahari pada wajah, leher, lengan, dan kaki selama 10-15 menit dapat menghasilkan 1.000 unit internasional (IU) sampai $3.000 \mathrm{IU}$, tergantung pada jenis kulit dan kebutuhan vitamin D yang diperlukan oleh tubuh masing-masing dalam satu hari.Vitamin D berfungsi untuk meningkatkan penyerapan kalsium di dalam usus dan mentransfer kalsium melintasi membaran sel, sehingga dapat menguatkan tulang. Vitamin D juga dapat memberikan perlindungan terhadap jenis kanker (seperti kanker paru-paru, prostat, dan kulit), osteoporosis, rakhitis, dan diabetes. Selain itu, vitamin D dapat membantu menurunkan kadar kolestrol darah sehingga membantu melawan penyakit jantung (Wiendartun, 2012).

Pengaruh sinar UVB terhadap kolesterol darah dapat membantu penurunan kadar kolesterol melalui proses waktu berkas sinar ultraviolet mengenai kulit maka sinar ini akan disaring di kulit, di bawah kulit terdapat sejumlah besar simpanan kolesterol. Sinar ultraviolet mengubah simpanan kolesterol ini menjadi vitamin D (Suheimi, 2008). 


\section{KESIMPULAN}

Golongan umur responden terbanyak antara 60-70 tahun, frekuensi 12 dengan prosentase $42 \%$. Jenis kelamin responden yang paling banyak perempuan dengan frekuensi 24 dan prosenstase $80 \%$, sedangkan laki laki $20 \%$. Responden kelompok intervensi pre test yang mempunyai kepadatan massa tulang dengan resiko tinggi $\mathrm{T}$-score $-4,5$ sampai $-4,0$ terbanyak dengan jumlah 7 responden setelah post test antara mempunyai kepadatan massa tulang responden terbanyak dengan $\mathrm{T}$ score -2,9 sampai 2,5 sebanyak 3 responden. Kadar kolesterol responden kelompok intervensi pre test dengan score 200-250 sebanyak 10 responden sedangkan251-330 sebanyak 5 responden. Kadar kolesterol 200-250 sebanyak 8 responden sedangkan251-330 sebanyak 2 responden sedangkan score $<200$ sebanyak 5 responden.

\section{DAFTAR PUSTAKA}

Fonterra. 2013. Epidemiology, Costs and Burden of Osteoporosis in Asia Pacific Regional Audit. (Diakses 2 April 2014).

Darmojo \& Martono. 2006. Buku Ajar Geriatri (Ilmu Kesehatan Usia Lanjut). Jakarta: Balai Penerbit FKUI.

Kompas Health. 2013. Tinggi Prevalensi dan Risiko Akibat Osteoporosis. http://health. kompas.com/read/2013/12/14/0935056/.

(Diakses 23 April 2015).

Wiendartun. 2012. Cahaya, http://file.upi.edu/ Direktori/FPMIPA/JUR._PEND._FISIKA/ 195708071982112-WIENDARTUN/2-_Ca haya_Mklh.pdf. (Diakses 23 April 2015). 